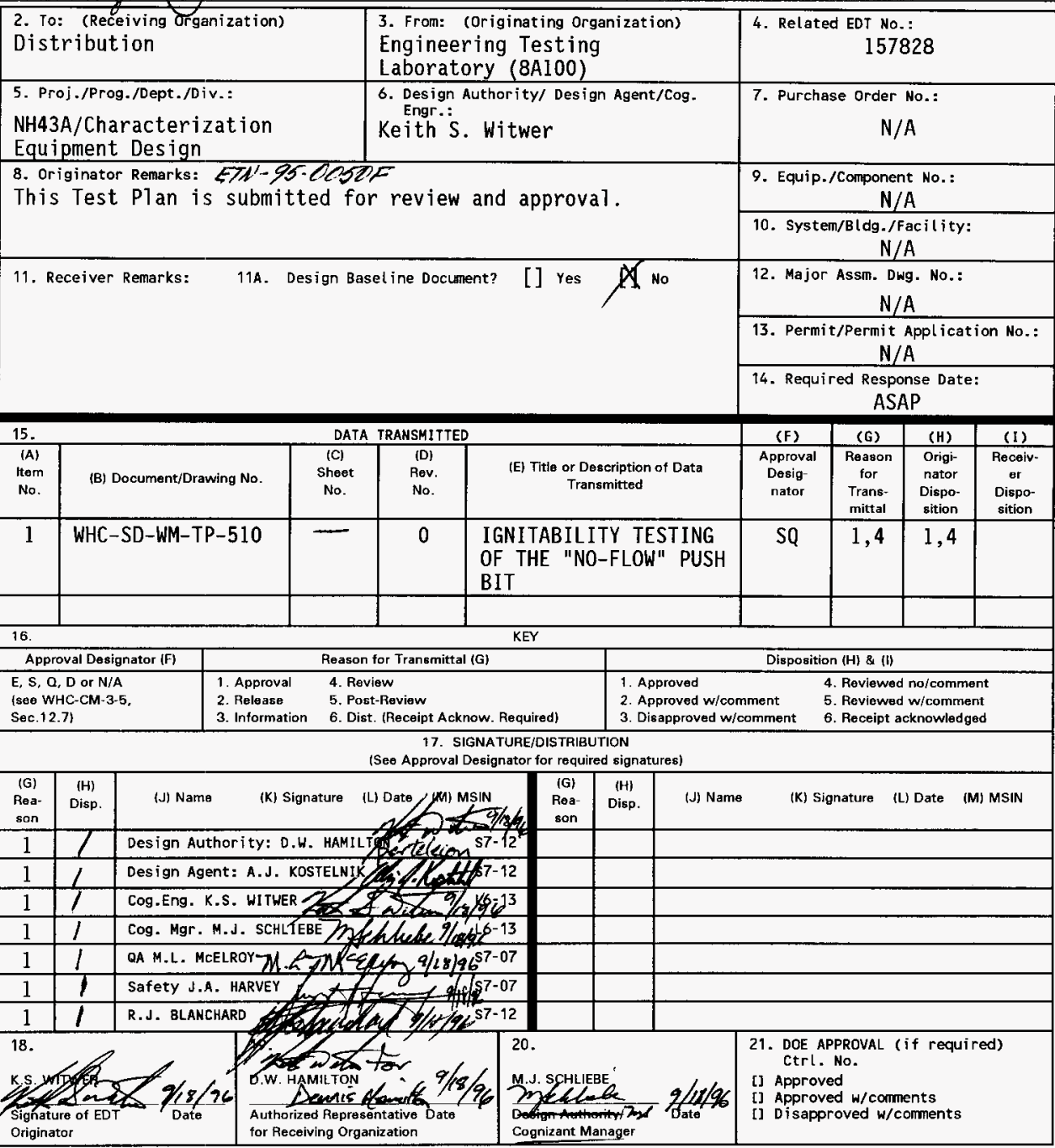

BD-7400-172-2(05/96) GEF097 


\section{Ignitability Testing of the "No-Flow" Push Bit}

\section{Keith S. Witwer}

Westinghouse Hanford Co., Richland, WA 99352

U.S. Department of Energy Contract DE-ACO6-87RLI0930

$\begin{array}{llll}\text { EDT/ECN: } & 157829 & \text { UC: } 2070 \\ \text { Org Code: } & 8 A 100 & \text { Charge Code: } & \text { N4H3A } \\ \text { B\&R Code: } & \text { EW3120074 } & \text { Total Pages: } & 15\end{array}$

Key Words: Universal Sampler, No-Flow Push Bit, Ignitability, US Bureau of Mines,

Abstract: Testing will determine if an ignition occurs during the drop of a Universal Sampler onto a push-mode bit in a flammable gas environment. Ten drops each of the sampler using both a push-mode and rotary mode insert onto a push-mode bit will be completed. If an ignition does not occur under the conditions set forth in this test, then a satisfactory level of confidence will be obtained which would allow field operations using these inserts and drill bit.

TRADEMARK DISCLAIMER. Reference herein to any specific commercial product, process, or service by trade name, trademark, manufacturer, or otherwise, does not necessarily constitute or imply its endorsement, recormendation, or favoring by the United States Governent or any agency thereof or its contractors or subcontractors.

Printed in the United States of America. To obtain copies of this document, contact: WHC/BCS Document Control Services, P.O. Box 1970, Mailstop H6-08, Richland WA 99352, Phone (509) 372-2420; Fax (509) 376-4989.
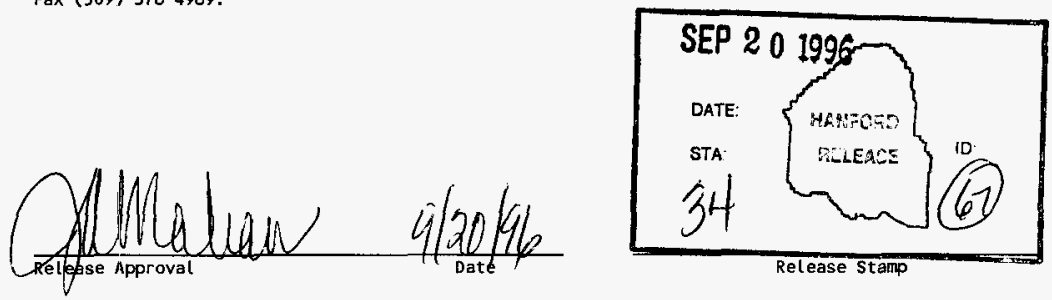

Approved for Public Release 


\title{
IGNITABILITY TESTING OF THE NO-FLOW PUSH BIT
}

\author{
WHC-SD-WM-TP-510 \\ REV. 0
}

SEPTEMBER 10, 1996

\author{
Keith S. Witwer \\ Engineering Testing Laboratory \\ Westinghouse Hanford Company \\ Richland, Washington
}




\section{TABLE OF CONTENTS}

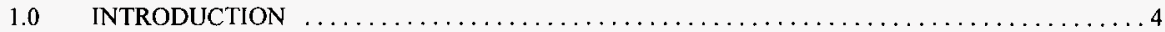

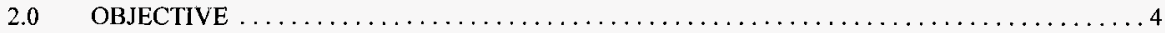

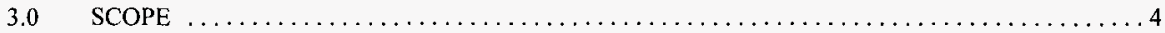

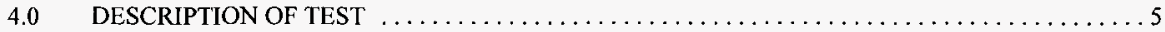

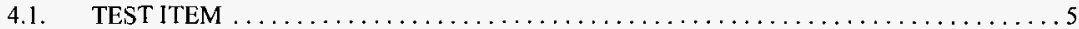

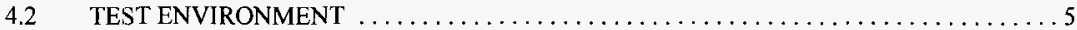

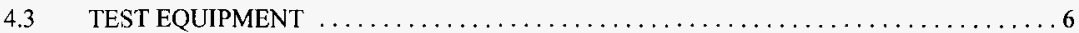

4.3.1 SAMPLER, INSERTS, AND PUSH-MODE BIT $\ldots \ldots \ldots \ldots \ldots \ldots \ldots \ldots \ldots$

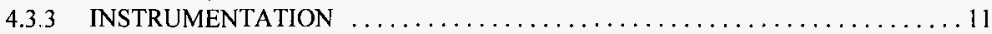

4.3.4 DRILL STRING, SAMPLER AND RELEASE EQUIPMENT $\ldots \ldots \ldots \ldots \ldots \ldots \ldots 11$

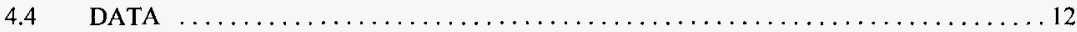

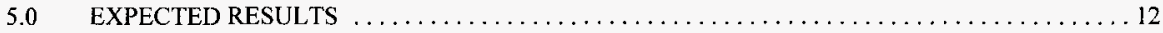

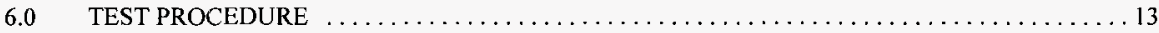



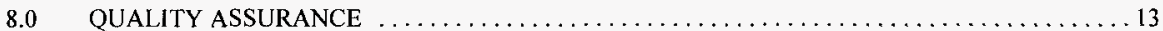

9.0 ORGANIZATIONAL RESPONSIBILITIES $\ldots \ldots \ldots \ldots \ldots \ldots \ldots \ldots \ldots \ldots \ldots \ldots \ldots \ldots \ldots$

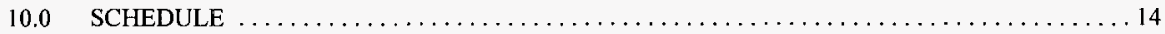

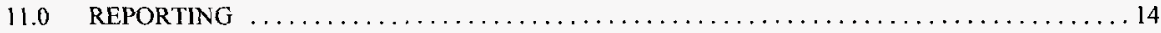

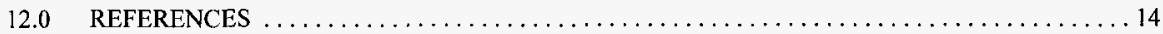


WHC-SD-WM-TP-510

REV. 0

PAGE 3 OF 14

\section{LIST OF FIGURES}

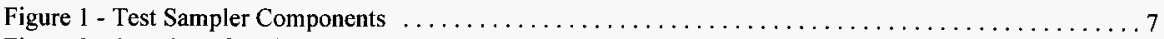

Figure 2 - Drawing of Push Mode Sampler Insert $\ldots \ldots \ldots \ldots \ldots \ldots \ldots \ldots \ldots \ldots \ldots \ldots \ldots \ldots \ldots \ldots \ldots$

Figure 3 - Drawing of Rotary-Mode Sampler Insert $\ldots \ldots \ldots \ldots \ldots \ldots \ldots \ldots \ldots \ldots \ldots \ldots \ldots \ldots \ldots$

Figure 4 - Drawing of "No-Flow" Push Bit $\ldots \ldots \ldots \ldots \ldots \ldots \ldots \ldots \ldots \ldots \ldots \ldots \ldots \ldots \ldots \ldots \ldots$

\section{LIST OF PHOTOGRAPHS}

Photograph 1 - "No-Flow" Push-mode Bit $\ldots \ldots \ldots \ldots \ldots \ldots \ldots \ldots \ldots \ldots \ldots \ldots \ldots \ldots \ldots \ldots \ldots \ldots \ldots$

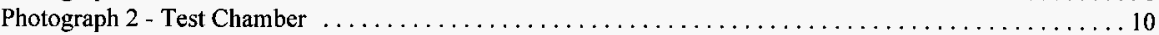

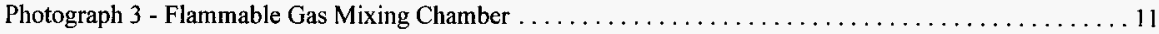

\section{LIST OF TABLES}

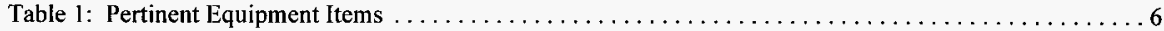

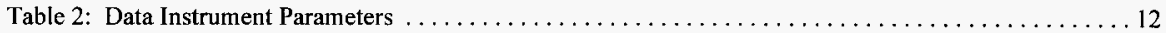




\section{IGNITABILITY TESTING OF THE NO FLOW PUSH BIT}

\subsection{INTRODUCTION}

The recently completed Safety Assessment for Core Sampling in Flammable Gas Watch List Tanks ${ }^{1}$ (Safety Assessment) discussed the possibility of inadvertent rotary-mode sampling with a push-mode drill bit. The push-mode bit does not have rotary cutting surfaces or purge hole cooling ports for nitrogen flow. It would not penetrate harder waste layers when rotated and would subsequently heat up to excessively high temperatures. This is a safety concern due to the possibility of igniting the flammable gasses that could be present in the waste. To eliminate this possibility of rotary-mode sampling with a push-mode bit, the push bit and sampler insert sections were recently redesigned to prevent purge gas from flowing past the sampler ${ }^{2}$. Safety interlocks on the Rotary Mode Core Sampling System (RMCSS) prevent it from drilling in rotary mode without a minimum of 30 SCFM flowing through the drill string and drill bit. By designing the geometry of the push-mode bit to limit this purge flow to less than 30 SCFM, the RMCSS is prevented from going into rotarymode with a push-mode bit installed and the safety concern is effectively eliminated.

The newly designed sampler insert incorporates a knife edge sealing surface between the insert and the core drilling bit. The combination of this knife seal and more closely controlled clearance tolerances between the moving components of the rotary insert provide a sampler that allows less than 10 SCFM gas purge flow through the push mode bit.

The Safety Assessment dictates that this change in geometry of the drill bits and sampler inserts require ignitability proof testing. In this case, the testing will determine if an ignition of flammable gasses could occur if a sampler were accidentally to drop onto a drill bit mounted in the end of a length of drill string. Previous ignitability testing ${ }^{3}$ showed that a stoichiometric gas mixture of hydrogen and air would be bounding for the drop tests and this mixture will also be used in this testing. The contact surface where the sampler insert touches the drill bit is the same geometry and material composition for both the push-mode bit and the rotarymode bit. Therefore, only the push-mode bit will be used for testing.

\subsection{OBJECTIVE}

Testing will determine if an ignition occurs during the drop of a sampler onto a push-mode bit in a flammable gas environment. Ten drops each of the sampler using both a push-mode and rotary mode insert onto a push-mode bit will be completed. If an ignition does not occur under the conditions set forth in this test, then a satisfactory level of confidence will be obtained which would allow field operations using these inserts and drill bit.

\subsection{SCOPE}

This testing is directed by the Westinghouse Characterization Equipment Engineering Group and will be done by the Engineering Testing Laboratory (ETL) and the United States Bureau of Mines (USBM) personnel at the Pittsburgh Research Center in Pennsylvania. A Statement of Work (SOW) which describes the test specifications \& accuracy, deliverables, schedule, cost, responsibilities, etc. as well as an extension to the current Memorandum of Agreement 14-09-005-3666 between WHC and the USBM supports this testing.

USBM will provide consultation, design information, test support, and test results. ETL will provide the results from this testing in a supporting document to the Characterization Equipment Group. 


\subsection{DESCRIP'TION OF TEST}

\subsection{TEST ITEM}

A sixty-foot length of standard 2.25 inch (OD) steel drill string will be supported vertically with a crane or other holding device such that the lower twelve inches of the drill string is positioned within a heated $\left(100^{\circ} \mathrm{C}\right)$ steel test chamber. After purging air from the test chamber and drill string with a stoichiometric hydrogen and air gas mixture, a sampler, with a new insert (rotary or push mode) installed, will be dropped within the drill string. The maximum height of an accidental drop of a sampler in a drill string during field sampling operations is sixty feet and will be the height of the drop in this testing.

During a typical drop, a "catch and release" mechanism will be lowered down in the drill string onto the sampler. The mechanism will grab the sampler and an operator will raise the sampler to the top of the drill string. The drill string will then be purged and filled with flammable gas. An operator will start the data acquisition equipment recording pertinent test parameters and will signal a second operator to release the sampler. This second operator will then tug sharply on the holding cable which will release the sampler down into the drill string and onto the drill bit. If no ignition occurs during the drop, an ignition will be intentionally induced immediately after the drop using an electric match - to verify the flammability of the gas mixture. If no ignition occurs during the drop (a "successful" test), the test will be repeated nine more times for a total of ten drops. Ten drops will be repeated for the other insert style as well. No ignition is expected because of the non sparking composition of the sampler inserts and drill bit. If there is an ignition during a drop, testing will be suspended to allow further consultation and planning.

\subsection{TEST ENVIRONMENT}

Testing will be conducted at the Pittsburgh Research Center in Pittsburgh, PA. The USBM Fires, Explosives and Explosions Group will be responsible for the actual testing site and necessary support equipment. The Pittsburgh facility is ideally suited for these tests since it is designed to handle the potential explosion hazard. Testing will occur in an area that is physically separated, by a safety barrier, from test personnel. USBM standard operating procedures and safety oversight will be in effect for these tests. 
WHC-SD-WM-TP-510

REV. 0

PAGE 6 OF 14

\subsection{TEST EQUIPMENT}

Table 1 below shows the pertinent equipment items with their corresponding identification numbers.

Table 1: Pertinent Equipment Items

\begin{tabular}{|c|c|}
\hline Equipment Item & Part/Drawing Number \\
\hline Sampler & N/A (shop built for this testing)* \\
\hline Push Mode Bit & Longyear" P/N $1000 \mathrm{VD} / 1$ \\
\hline Push Mode Insert & TBD \\
\hline Rotary Mode Insert & TBD \\
\hline Five Foot steel drill string & Longyear P/N 200182 \\
\hline Core Barrel & H-2-821457-13 \\
\hline
\end{tabular}

\subsubsection{SAMPLER, INSERTS, AND PUSH-MODE BIT}

Figure 1 shows the test sampler to be used for the drop testing. Because the end section of the sampler is deformed during a drop, this two-piece sampler will be used rather than a single piece Universal Sampler. This will allow the head section to be replaced as needed rather than using an entire new sampler for each drop. Since the only parameter of interest for this series of drop testing is the impact zone between the insert and the Push Bit, other differences in geometry between the test sampler and Universal Sampler are not critical. One such difference is the edges on the quadralatch mechanism - mounted at the top of the sampler. This edge normally catches on the serrated edges on the inner diameter of the sample tube to hold the sampler in place. These edges are ground off for this testing to provide easier retrieval of the sampler after a drop. Previous ignitability testing addressed this contact surface as a source of ignition and is therefore not an area of concern for this testing. This two-piece sampler has the same outer diameter and is the same weight as the Universal Sampler - giving it the same free-fall characteristics, i.e., the same impact velocity. 
WHC-SD-WM-TP-510

REV. 0

PAGE 7 OF 14

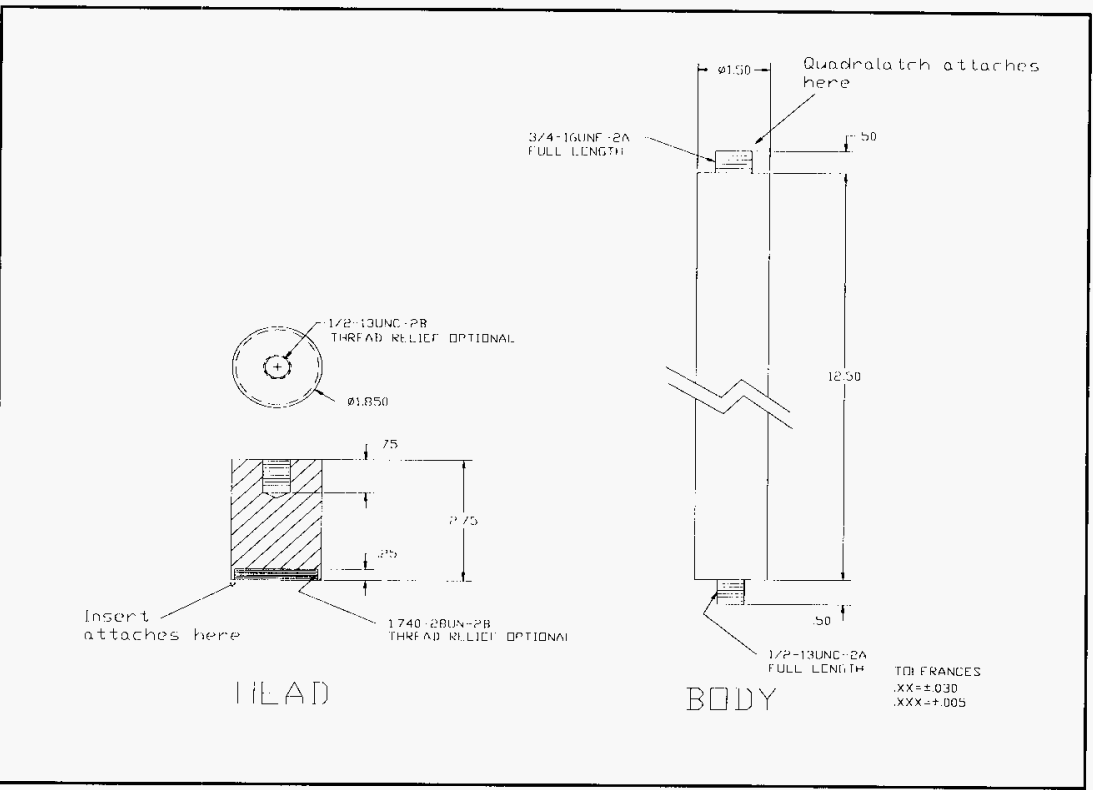

Figure 1 - Test Sampler Components



(74) PUSH INSERT

Figure 2 - Drawing of Push Mode Sampler Insert 
WHC-SD-WM-TP-510

REV. 0

PAGE 8 OF 14

Figures 2 and 3 show the push and rotary mode sampler inserts, respectively. As shown, the rotary insert is of a two-piece inner and outer race construction while the push insert is a one piece construction. The inserts are made of Monel (the ball bearings mounted inside the rotary insert are made of a chrome alloy steel).

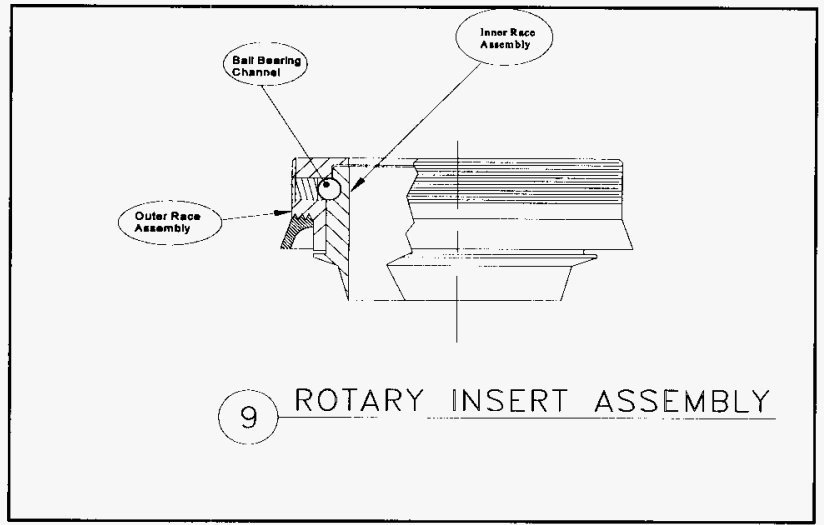

Figure 3 - Drawing of Rotary-Mode Sampler Insert

Photograph 1 - "No-Flow" Push-mode Bit

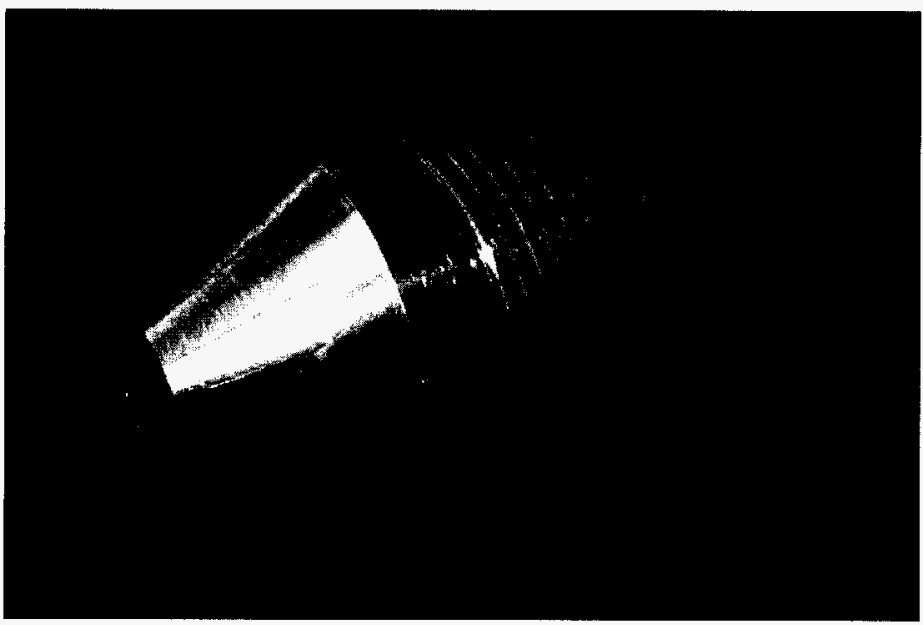


WHC-SD-WM-TP-510

REV. 0

PAGE 9 OF 14

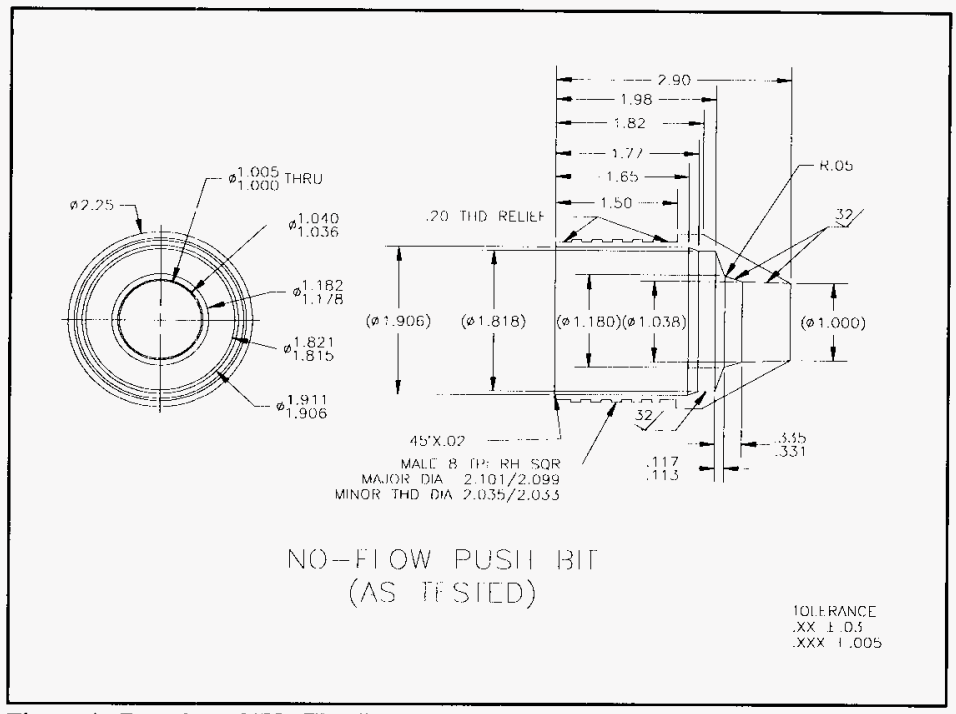

Figure 4 - Drawing of "No-Flow" Push Bit

Photograph 1 and Figure 4 above show the Push-Mode bit. It is constructed in two pieces with the upper threaded section made of 1026 carbon steel which is fused onto the lower (brass and tungsten carbide matrix) cutting section.

\subsubsection{IGNITION TEST CHAMBER}

As seen in Photograph 2 below, a small 15 liter test chamber will be used to contain the flammable gas and drill string. This chamber will be sealed so that the flammable gas environment can be closely controlled. If an ignition of the flammable gas occurs, the chamber is constructed with thin diaphragms on the walls that will rupture and allow the sudden pressure to vent, thereby protecting the test chamber and any surrounding test equipment.

The flammable gas will flow from a separate 120 liter (pressurized) mixing chamber via copper tubing to the test chamber and be distributed within the test chamber via a circular copper tube placed in the bottom of the test chamber. Previous ignitability testing under similar conditions showed that eight minutes of purge at a rate of $28 \mathrm{liter} / \mathrm{min}$ is sufficient to fully purge both the test chamber and the sixty feet of drill string of any atmospheric gasses initially present. The flow rate will be reduced to approximately 6 liters $/ \mathrm{min}$ after this initial eight minute purge for the duration of the test to maintain a flammable environment. 
WHC-SD-WM-TP-510

REV. 0

PAGE 10 OF 14

\section{Photograph 2 - Test Chamber}

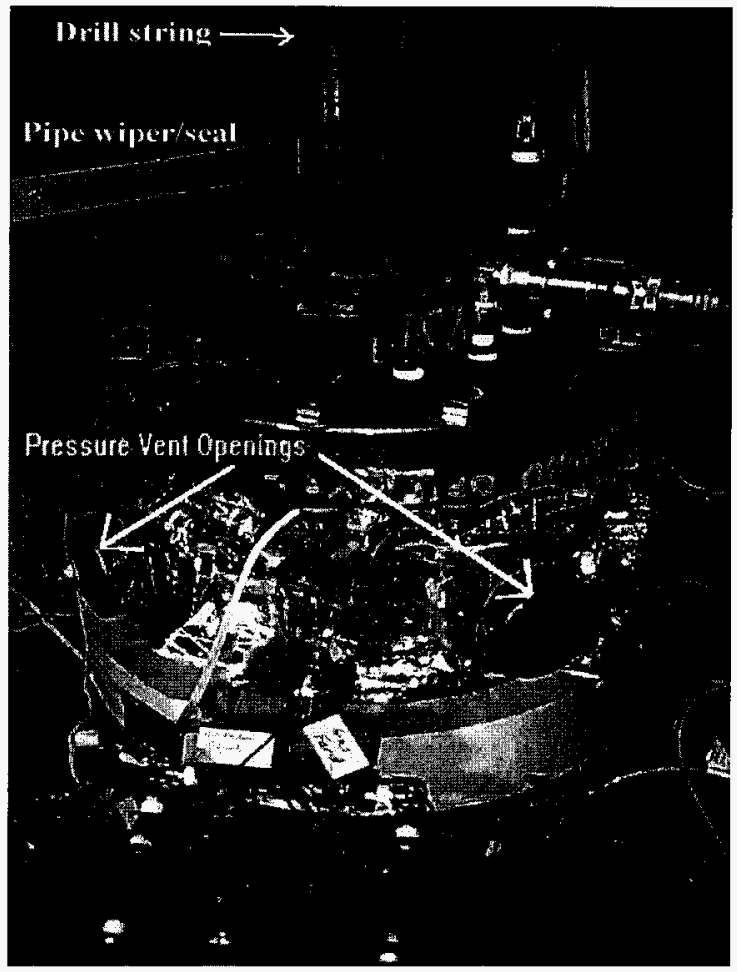

The pressurized mixing chamber, shown in Photograph 3 below, is used to provide the flammable gas to the test chamber. A vacuum is initially pulled on the mixing chamber and individual gas species are then supplied at the required partial pressures to create the stoichiometric hydrogen/air mixture. The mixing chamber supplies a fully mixed gas for both the initial purging of the test chamber and a continuous 6 liters/min gas flow rate to maintain a slight positive pressure in the chamber during testing. 
WHC-SD-WM-TP-510

REV. 0

PAGE 11 OF 14

\section{Photograph 3 - Flammable Gas Mixing Chamber}

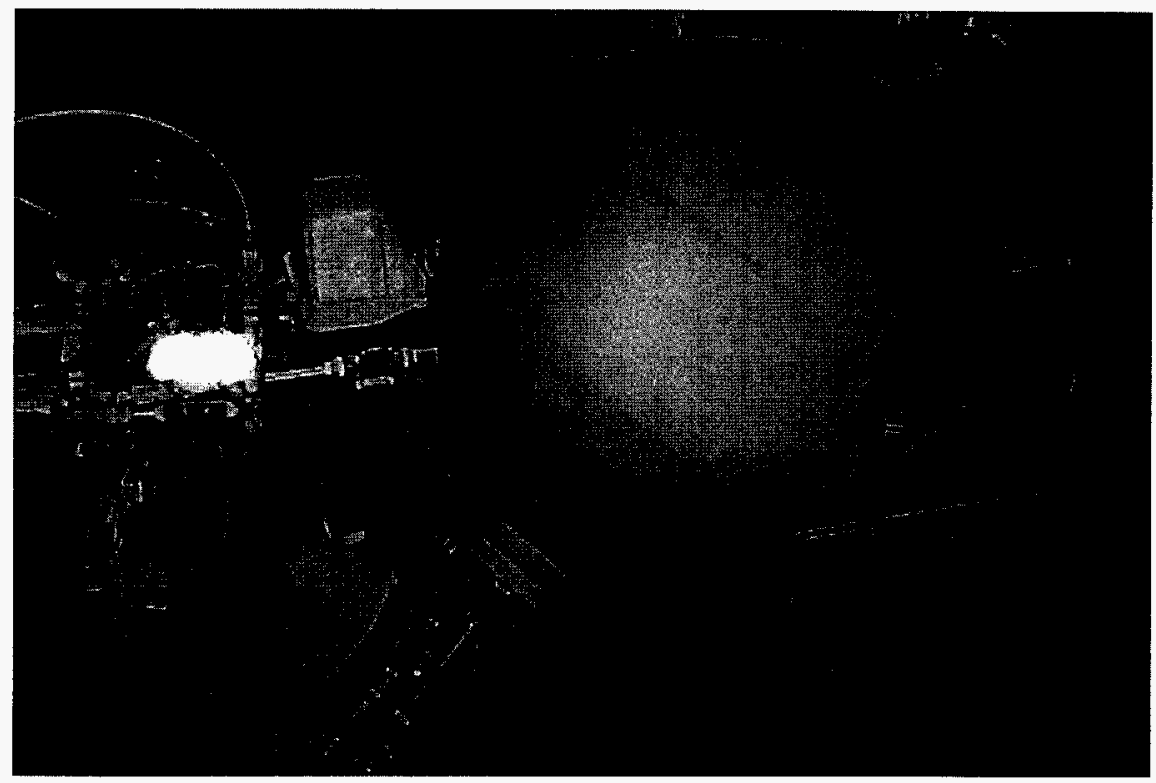

\subsubsection{INSTRUMENTATION}

Pressure transducers and flame sensors mounted in the test chamber will indicate the timing and magnitude of an ignition. In addition, a spark inducing device, such as an electric match, will be installed to provide an intentional ignition of the flammable gas. Information from the sensors will be fed to a remote data acquisition system for recording. Flow sensors on the gas feed-line between the 120 liter pressurized mixing chamber and the 15-liter test chamber provide remote indication and control of the flow rate.

\subsubsection{DRILL STRING, SAMPLER AND RELEASE EQUIPMENT}

Standard five foot sections of steel drill string will be screwed together to provide the sixty feet needed. A cable and pulley arrangement will be mounted at the top of the drill string. A remote latching unit release mechanism that hangs within the drill string will be attached to one end of the cable and a handle (for an operator to hold on to at ground level) will be attached to the other end. 


\subsection{DATA}

Data will be collected both electronically using a PC, and in a laboratory log book ${ }^{4}$. Parameters of interest include the pressure and time of an ignition during a drop (should one occur), partial pressures of the hydrogen and oxygen flowing into the mixing chamber, and flow rate of the flammable gas from the mixing chamber into the test chamber. Table 2 below lists specific information for key data instruments.

Table 2: Data Instrument Parameters

\begin{tabular}{|c|c|c|}
\hline Equipment Item & Accuracy/Sensitivity & Type/Range \\
\hline $\begin{array}{l}\text { H, Partial Pressure Transducer } \\
\text { (mounted on inlet line to mixing } \\
\text { chamber) }\end{array}$ & $\begin{array}{c}+/-0.1 \text { psi or }+/-0.5 \% \\
\text { (whichever is larger) }\end{array}$ & $\begin{array}{l}\text { Strain Gage } \\
0-50 \text { psia }\end{array}$ \\
\hline $\begin{array}{l}\text { O Partial Pressure Transducer } \\
\text { (mounted on inlet line to mixing } \\
\text { chamber) }\end{array}$ & $\begin{array}{c}+/-0.1 \text { psi or }+/-0.5 \% \\
\text { (whichever is larger) }\end{array}$ & $\begin{array}{c}\text { Strain Gage } \\
0-50 \text { psia }\end{array}$ \\
\hline $\begin{array}{l}\text { Explosion Pressure Transducer } \\
\text { (mounted in test chamber) }\end{array}$ & $\begin{array}{l}+/-0.2 \text { psi or }+/-1 \% \\
\text { (whichever is larger) }\end{array}$ & $\begin{array}{c}\text { Strain Gage } \\
0-100 \text { psia or } 0-200 \text { psia }\end{array}$ \\
\hline $\begin{array}{l}\text { Explosion Flame Sensor } \\
\text { (Mounted near vent opening in } \\
\text { test chamber) }\end{array}$ & $\begin{array}{c}\text { Qualitative } \\
\text { (presence of flame) }\end{array}$ & Photo Diode \\
\hline High Speed Camera & 200 frames $/ \mathrm{sec}$ & High Speed V.H.S. \\
\hline
\end{tabular}

\subsection{EXPECTED RESULTS}

The testing will be considered successful if no ignition occurs after ten 60 foot drops of a sampler onto a Push-Mode bit for each insert style. No ignitions are expected due to the non sparking nature of the drill bit and sampler insert material. 


\subsection{TEST PROCEDURE}

Below is the step-by-step procedure to be used for the tests.

1) Position a sampler with a new insert up into the core barrel and attach to the remote latching unit suspended with the drill string. Screw a new style drill bit onto the end of the core barrel.

2) Raise the sampler to the top of the sixty feet of drill string using the cable. Secure the cable to a fixed support.

3) Place a rubber drill string pipe-wiper and steel flange over drill pipe and lower drill string (or raise the test chamber) so that the end of drill bit is positioned approximately in the middle of the test chamber. Secure the steel flange to the test chamber.

4) Insure that the internal air space in the test chamber is at approximately $100^{\circ} \mathrm{C}$ and begin filling with the flammable gas mixture. Continue filling at 28 liters $/ \mathrm{min}$ for eight minutes. After eight minutes, reduce the flow rate of flammable gas to 6 liters/min for duration of the test. Insure that the test chamber internal temperature is at least $100^{\circ} \mathrm{C}$ but not greater than $110^{\circ} \mathrm{C}$.

5) Insure that personnel are safely located away from the test chamber and drill string and begin recording with data acquisition system.

6) Sharply pull on the holding cable allowing the sampler to drop through the drill string onto the drill bit.

7) If no ignition occurs during the drop, ignite the gas mixture using an electric match, then stop recording with DAS. If no ignition occurs with an electric match, identify cause and repeat the test (consider this non igniting test to be invalid). If an ignition does occur during the drop, stop testing with this test item. Otherwise, prepare for another drop and repeat the above sequence until ten drops are completed.

\subsection{SAFETY}

An explosion (detonation or deflagration) hazard exists. The USBM has facilities, personnel, and safety procedures prepared to accommodate an explosion, should one occur.

\subsection{QUALITY ASSURANCE}

The pertinent measuring devices will be calibrated or characterized by the USBM before use. Information concerning each test will be recorded in an official WHC log book by the Test Director - Keith Witwer (or alternate). 


\subsection{ORGANIZATIONAL RESPONSIBILITIES}

\section{Engineering Testing Laboratory - WHC}

Responsible for test direction and for provision and transportation of major components needed for testing to the USBM Pittsburgh Research Center and back to Hanford at conclusion of testing. WHC is also responsible for the final test report writing and release. WHC Cognizant Engineer is Keith Witwer. Other WHC points of contact are Roy Blanchard, Dennis Hamilton, and A1 Kostelnik of WHC Characterization Equipment Engineering.

\section{Pittsburgh Research Center. USBM-Pittsburgh}

Responsible for providing the testing facility, the setup of testing, various flammable gas hardware and instrumentation, support personnel, and assistance in preparing a final test report. This testing falls under a Memorandum of Agreement ${ }^{5}$ between WHC and USBM. USBM points of contact are Kenneth L. Cashdollar and Aldo Furno of the Fires, Explosives and Explosions Group.

\subsection{SCHEDULE}

WHC personnel will travel to Pittsburgh approximately one week after shipment of necessary drill equipment. The setup of the equipment will commence as soon as possible and actual testing will begin shortly after that. Testing is estimated to take between one to two weeks and is expected to start the third week in September 1996.

\subsection{REPORTING}

A Supporting Document Test Report will be generated and delivered to Characterization Equipment Engineering within three weeks after completion of testing.

\subsection{REFERENCES}

1. Unal, C. et al. " A Safety Assessment for Push-Mode and Rotary-Mode Core Sampling in Flammable Gas single Shell Tanks: Hanford Site, Richland, Washington, WHC-SD-WM-SAD-035, Rev. 0 , Westinghouse Hanford Company.

2. Witwer, K.S., WHC-SD-WM-TRP-264 - "Report On The Testing of The "No-Flow" Push Bit", 9/96.

3. Witwer, K.S., WHC-SD-WM-TRP-257, Rev 0, "Test Report for Core Drilling Ignitability Testing", 8/96.

4. Laboratory Logbook “Ignitability Testing for Core Drilling System” WHC-N-984-1, K. Witwer custodian

5. MOA 14-09-005-3666, P. D. Braun, WHC, to John Murphy, U.S. Bureau of Mines, PMM-PDB026, March 12, 1996. 


\section{DISTRIBUTION SHEET}

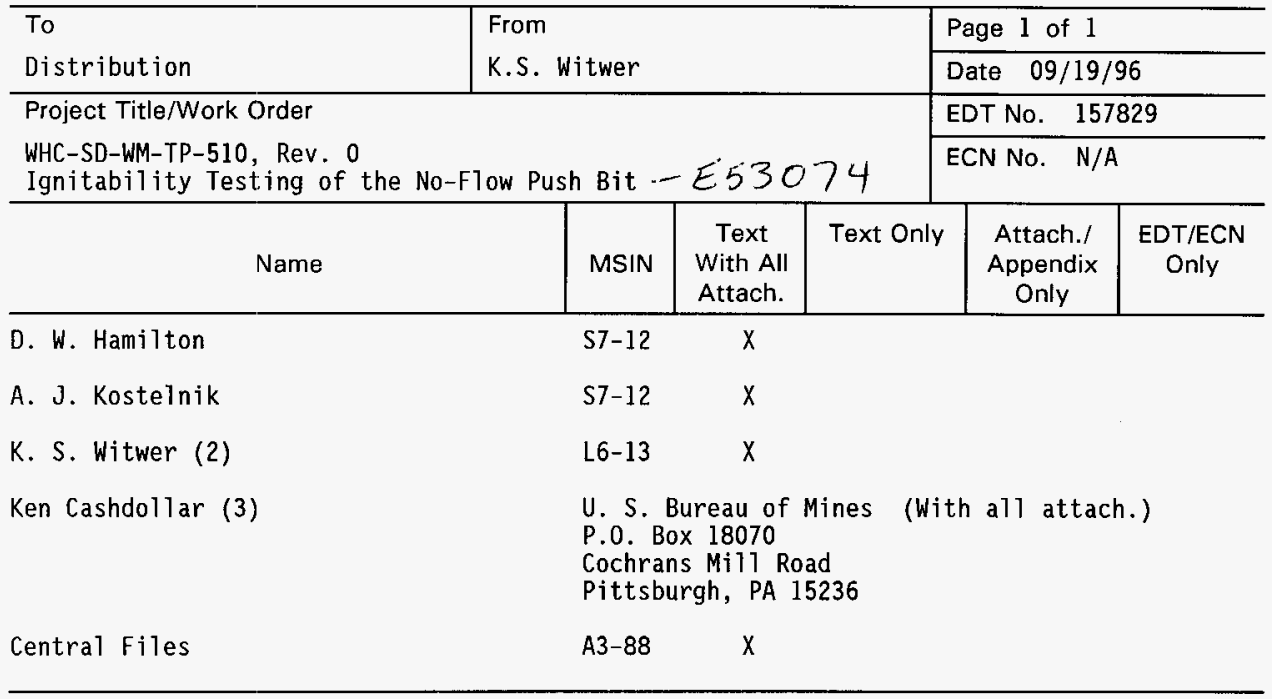

